\title{
The platelet $\mathrm{P} 2 \mathrm{Y}_{12}$ receptor under normal and pathological conditions. Assessment with the radiolabeled selective antagonist $\left[{ }^{3} \mathrm{H}\right]$ PSB-0413
}

\author{
Philippe Ohlmann • Anna Lecchi • Ali El-Tayeb • \\ Christa E. Müller • Marco Cattaneo • Christian Gachet
}

Received: 28 March 2012 / Accepted: 30 July 2012 / Published online: 15 August 2012

(C) Springer Science+Business Media B.V. 2012

\begin{abstract}
Various radioligands have been used to characterize and quantify the platelet $\mathrm{P} 2 \mathrm{Y}_{12}$ receptor, which share several weaknesses: (a) they are metabolically unstable and substrates for ectoenzymes, (b) they are agonists, and (c) they do not discriminate between $\mathrm{P}_{2} \mathrm{Y}_{1}$ and $\mathrm{P} 2 \mathrm{Y}_{12}$. We used the $\left[{ }^{3} \mathrm{H}\right] \mathrm{PSB}-0413$ selective $\mathrm{P} 2 \mathrm{Y}_{12}$ receptor antagonist radioligand to reevaluate the number of $\mathrm{P}_{2} \mathrm{Y}_{12}$ receptors in intact platelets and in membrane preparations. Studies in humans showed that: (1) $\left.{ }^{3} \mathrm{H}\right] \mathrm{PSB}-0413$ bound to $425 \pm 50$ sites/platelet $\left(K_{\mathrm{D}}=3.3 \pm 0.6 \mathrm{nM}\right),(2) 0.5 \pm 0.2 \mathrm{pmol}\left[{ }^{3} \mathrm{H}\right]$ PSB-0413 bound to $1 \mathrm{mg}$ protein of platelet membranes $\left(K_{\mathrm{D}}=6.5 \pm 3.6 \mathrm{nM}\right)$, and (3) competition studies confirmed the known features of $\mathrm{P} 2 \mathrm{Y}_{12}$, with the expected rank order of potency: AR-C69931MX $>2$ MeSADP $\gg$ ADP $\beta S>A D P$,
\end{abstract}

A. El-Tayeb is on leave from the University of Al-Azhar, Assiut, Egypt.

P. Ohlmann · C. Gachet $(\bowtie)$

UMR_S949 INSERM-Université de Strasbourg, EFS-Alsace,

10 rue Spielmann,

67065 Strasbourg, France

e-mail: christian.gachet@efs-alsace.fr

A. Lecchi

Angelo Bianchi Bonomi Hemophilia and Thrombosis Center,

Department of Internal Medicine, Foundation

IRCCS Ca'Granda Ospedale Maggiore Policlinico

and Università degli Studi di Milano,

Milan, Italy

A. El-Tayeb · C. E. Müller

PharmaCenter Bonn, Pharmaceutical Institute,

Pharmaceutical Chemistry I, University of Bonn,

An der Immenburg 4,

53121 Bonn, Germany

M. Cattaneo

Unità di Medicina 3 Ospedale San Paolo,

Dipartimento di Medcina, Chirurgia e Odontoiatra,

Università degli Studi di Milano,

Milan, Italy

while the $\mathrm{P}_{2} \mathrm{Y}_{1}$ ligand MRS2179 and the $\mathrm{P}_{2} \mathrm{X}_{1}$ ligand $\alpha, \beta$-Met-ATP did not displace $\left[{ }^{3} \mathrm{H}\right] \mathrm{PSB}-0413$ binding. Patients with severe $\mathrm{P}_{2} \mathrm{Y}_{12}$ deficiency displayed virtually no binding of $\left[{ }^{3} \mathrm{H}\right] \mathrm{PSB}-0413$ to intact platelets, while a patient with a dysfunctional $\mathrm{P}_{2} \mathrm{Y}_{12}$ receptor had normal binding. Studies in mice showed that: (1) $\left[{ }^{3} \mathrm{H}\right] \mathrm{PSB}-0413$ bound to $634 \pm 87$ sites/platelet $\left(K_{\mathrm{D}}=14 \pm 4.5 \mathrm{nM}\right)$ and (2) $0.7 \mathrm{pmol} \pm 0.3\left[{ }^{3} \mathrm{H}\right] \mathrm{PSB}-0413$ bound to $1 \mathrm{mg}$ protein of platelet membranes $\left(K_{\mathrm{D}}=9.1 \pm 5.3 \mathrm{nM}\right)$. Clopidogrel and other thiol reagents like pCMBS or DTT abolished the binding both to intact platelets and membrane preparations. Therefore, $\left[{ }^{3} \mathrm{H}\right] \mathrm{PSB}-0413$ is an accurate and selective tool for radioligand binding studies aimed at quantifying $\mathrm{P}_{2} \mathrm{Y}_{12}$ receptors, to identify patients with $\mathrm{P} 2 \mathrm{Y}_{12}$ deficiencies or quantify the effect of $\mathrm{P} 2 \mathrm{Y}_{12}$ targeting drugs.

Keywords $\mathrm{P}_{2} \mathrm{Y}_{12}$ receptor - Competitive antagonist . Radioligand $\cdot\left[{ }^{3} \mathrm{H}\right] \mathrm{PBS}-0413 \cdot$ Platelets $\cdot$ Nucleotide analog . AR-C67085MX

Abbreviations
AR-C67085MX
$\begin{aligned} & \text { AR-C69931MX } \\ & \text { (cangrelor) }\end{aligned}$

$\left[{ }^{3} \mathrm{H}\right] \mathrm{PSB}-0413$

PSB-0412 (precursor 2-Propargylthioadenosine-5'of $\left.\left[{ }^{3} \mathrm{H}\right] \mathrm{PSB}-0413\right)$

MRS2179
2-Propylthioadenosine-5'-adenylic acid (1,1-chloro-1-phosphonomethyl-1-phosphonyl)anhydride $N^{6}$-(2-Methylthioethyl)-2-(3,3,3trifluoropropylthio)adenosine-5'adenylic acid (1,1-chloro-1-phosphonomethyl-1-phosphonyl)anhydride $\left[{ }^{3} \mathrm{H}\right] 2$-Propylthioadenosine- $5^{\prime}$ adenylic acid (1,1-chloro-1-phosphonomethyl-1-phosphonyl)anhydride adenylic acid (1,1-chloro-1-phosphonomethyl-1-phosphonyl)anhydride $N^{6}$-Methyl-2'-deoxyadenosine-3', $5^{\prime}$ bisphosphate 
MRS2500

2-Iodo- $N^{6}$-methyl- $(N)$-methanocarba$2^{\prime}$-deoxyadenosine- $3^{\prime}, 5^{\prime}$ bisphosphate)

$p$ CMBS

para-Chloromercuribenzene sulfonic acid

\section{Introduction}

Platelet activation by ADP plays a crucial role in hemostasis and thrombosis, and their so-called $\mathrm{P} 2$ receptors are potential targets for antithrombotic drugs. Two $\mathrm{G}$ protein-coupled ADP receptors, $\mathrm{P} 2 \mathrm{Y}_{1}$ and $\mathrm{P} 2 \mathrm{Y}_{12}$, selectively contribute to platelet aggregation. The $\mathrm{P}_{2} \mathrm{Y}_{1}$ receptor is responsible for ADP-induced shape change, weak and transient aggregation, while the $\mathrm{P}_{2} \mathrm{Y}_{12}$ receptor is responsible for the completion and amplification of the response to ADP and to all platelet agonists including thromboxane $\mathrm{A}_{2}$, thrombin, and collagen [1]. Due to its central role in the formation and stabilization of a thrombus, the $\mathrm{P}_{2} \mathrm{Y}_{12}$ receptor is a wellestablished target of drugs like the thienopyridines (ticlopidine, clopidogrel, prasugrel) and ticagrelor which proved to have potent antithrombotic efficacy both in clinical trials in humans and in experimental models of thrombosis $[2,3]$. One important point is to be able to quantify the number of receptors expressed on platelets in order to assess the inter-individual variability in the general population, to characterize patients with inherited deficiencies, and to monitor and study patients treated with $\mathrm{P}_{2} \mathrm{Y}_{12}$ targeting drugs [4].

Various radioligands have been used to characterize and quantify the platelet $\mathrm{P} 2 \mathrm{Y}$ receptors such as, $\left[{ }^{14} \mathrm{C}\right] \mathrm{ADP}[5,6]$, $\left[{ }^{3} \mathrm{H}\right]$ ADP $[6,7],\left[{ }^{3} \mathrm{H}\right] 2$-methylthio-ADP $[8],\left[\beta-{ }^{32} \mathrm{P}\right] 2$-methylthio-ADP $[9,10]$, and $\left[\beta-{ }^{33} \mathrm{P}\right] 2$-methylthio-ADP [11], but they all share several weaknesses: (a) They are metabolically unstable and may be cleaved by a number of enzymes such as alkaline phosphatase and ectonucleotidases; (b) being agonists, they may complicate the quantification when intact, living cells are used and receptors are internalized upon activation; (c) they do not discriminate between $\mathrm{P} 2 \mathrm{Y}_{1}$ and $\mathrm{P} 2 \mathrm{Y}_{12}$ receptors. In the last decade, the only one possibility to selectively quantify $\mathrm{P} 2 \mathrm{Y}_{12}$ receptors was to use the non-selective radiolabeled ligand 2-methylthio-ADP in the presence of a $\mathrm{P} 2 \mathrm{Y}_{1}$ antagonist such as $N^{6}$-methyl-2'-deoxyadenosine-3',5'-bisphosphate (MRS2179) [12] or 2-iodo$N^{6}$-methyl- $(N)$-methanocarba-2'-deoxyadenosine-3', $5^{\prime}$ bisphosphate (MRS2500) [13]. Concerning P2 $\mathrm{Y}_{1}$, recent studies used the very selective antagonist MRS2500 as a radioligand $[14,15]$. From these studies, it is thought that platelets express approximately $150 \mathrm{P}^{2} \mathrm{Y}_{1}$ receptor copies/ cell. Concerning $\mathrm{P} 2 \mathrm{Y}_{12}$, based on earlier radioligand binding studies, the current idea is that individual platelets express around 450-1,000 copies. In the present study, we wished to more precisely quantify and characterize the $\mathrm{P}^{2} \mathrm{Y}_{12}$ receptors in intact platelets as well as in membrane fractions. To do that, we used the recently described $\left[{ }^{3} \mathrm{H}\right]$ PSB-0413 [16,17], which is a tritiated derivative of a selective antagonist of the $\mathrm{P}_{2} \mathrm{Y}_{12}$ receptor, the 2-propylthioadenosine-5'-adenylic acid $(1,1$ chloro-1-phosphonomethyl-1-phosphonyl)anhydride (ARC67085MX) compound. We also measured the binding to platelets from known patients, two with severe $\mathrm{P} 2 \mathrm{Y}_{12}$ deficiency $[6,18]$ and one with a dysfunctional $\mathrm{P} 2 \mathrm{Y}_{12}$ receptor [19] and from clopidogrel treated mice.

\section{Materials and methods}

\section{Subjects}

For experiments on human platelets, blood was taken from ten healthy subjects and three patients with congenital defects of the platelet P2Y12 receptors. Two patients (A and B) displayed severe deficiency of the receptors, which was associated with a homozygous frameshift mutation resulting in premature truncation of the protein in patient A $[6,20]$ or with heterozygous frameshift mutation resulting in premature truncation of the protein and haploinsufficiency in patient $\mathrm{B}[18,20]$. The platelets from the third patient displayed abnormal $\mathrm{P}_{2} \mathrm{Y}_{12}$-mediated responses to $\mathrm{ADP}$, but normal number of dysfunctional $\mathrm{P} 2 \mathrm{Y}_{12}$ receptors, associated with $\operatorname{Arg} 256$ to Gln transition in one allele and a Arg265 to Trp transition in the other allele [19].

\section{Chemicals}

$\left[{ }^{3} \mathrm{H}\right] \mathrm{PSB}-0413$ was prepared by catalytic hydrogenation with tritium gas (GE, Healthcare, Buckinghamshire, UK) of the propargyl precursor PSB-0412 as described [16]. Apyrase was purified from potatoes as previously described [21]. ARC69931MX (Cangrelor) was provided by the Medicines Company (Parsippany, NJ, USA). MRS2179 was purchased from TOCRIS (Bristol, UK). ADP was from Sigma-Aldrich Corp. (St. Louis, MO, USA). Clopidogrel was from SanofiAventis (Sanofi-Aventis, France). All other drugs were from Sigma-Aldrich Corp. (St. Louis, MO, USA).

\section{Cell culture}

Human astrocytoma 1321N1 cells (reference no. 80630402, European Collection of Cell Cultures, UK) stably expressing the $\mathrm{P} 2 \mathrm{Y}_{1}$ or the $\mathrm{P} 2 \mathrm{Y}_{12}$ receptor and subcloned were used for binding experiments and cultured as described previously [22]. For binding experiments, cells were removed by trypsinization and resuspended in PBS at a concentration of $2.10^{7}$ cells $/ \mathrm{ml}$. 
Preparation of washed platelet suspension

Human blood was collected from a forearm vein and mouse blood from the aorta under ether anesthesia acid-citratedextrose anticoagulant. Washed platelets from human or mouse blood were prepared as previously described [21]. Platelets were suspended in Tyrode's buffer $(137 \mathrm{mM} \mathrm{NaCl}$, $2 \mathrm{mM} \mathrm{KCl}, 12 \mathrm{mM} \mathrm{NaHCO} 3,0.3 \mathrm{mM} \mathrm{NaH} \mathrm{PO}_{4}, 1 \mathrm{mM}$ $\mathrm{MgCl}_{2}, 2 \mathrm{mM} \mathrm{CaCl} 2,5.5 \mathrm{mM}$ glucose, $5 \mathrm{mM}$ Hepes, $\mathrm{pH} 7.3$ ) containing $0.35 \%$ human serum albumin and apyrase $(0.02 \mathrm{U} / \mathrm{ml})$. The platelet count was adjusted at a concentration of 600,000 platelets $/ \mu$ l and the suspension maintained at $37^{\circ} \mathrm{C}$ until use.

Preparation of platelet membranes

Human platelet membranes were prepared essentially as described [23]. Briefly, washed platelets were resuspended in Tyrode's buffer containing no $\mathrm{Ca}^{2+}$, in the presence of $2 \mathrm{mM}$ EDTA and apyrase $(0.02 \mathrm{U} / \mathrm{ml})$ at room temperature. These platelets were loaded with glycerol by centrifugation through a $0-30 \%(v / v)$ glycerol gradient and lysed in a hypotonic Tris buffer containing $2 \mathrm{mM}$ EDTA and a cocktail of protease inhibitors. After lysis, the broken platelets were layered onto a $30 \%(w / v)$ sucrose cushion and centrifuged for $4 \mathrm{~h}$ at $60,000 \times \mathrm{g}$. The floating membranes were removed carefully with a plastic pipette, washed and pelleted by centrifugation for $1 \mathrm{~h}$ at $100,000 \times \mathrm{g}$. Mouse platelet membranes were prepared by nitrogen cavitation as described [24]. The broken platelets (crude membranes) were centrifuged at $30,000 \times g$ for $1 \mathrm{~h}$. Human plasma membrane pellets and mouse crude membrane pellets were resuspended in $50 \mathrm{mM}$ Tris $\mathrm{HCl}$, pH 7.5 containing $3 \%(v / v)$ glycerol. Protein concentrations from human and mouse platelet membranes were determined using the BCA assay and adjusted at $1 \mathrm{mg} / \mathrm{ml}$.

\section{Platelet aggregation}

Aggregation was measured at $37{ }^{\circ} \mathrm{C}$ by a turbidimetric method in a Carat TX4 aggregometer (Entec GmbH, Ilmenau, Germany). Platelets were activated by addition of $5 \mu \mathrm{M}$ ADP in the absence or presence of $100 \mathrm{nM}$ of $\left[{ }^{3} \mathrm{H}\right] \mathrm{PSB}-$ 0413 and human fibrinogen $(0.8 \mathrm{mg} / \mathrm{ml})$. The extent of aggregation was estimated quantitatively by measuring the maximum curve height above the baseline level.

Radioligand binding assay with human and mouse platelets

Binding experiments were performed with $200 \mu \mathrm{l}$ of human or mouse washed platelets or with $20 \mu \mathrm{g}$ of membrane proteins using $\left[{ }^{3} \mathrm{H}\right] \mathrm{PSB}-0413$ ranging from 0.030 to $50 \mathrm{nM}$ (hot saturation). Non-specific binding was defined in the presence of $1 \mathrm{mM}$ ADP. Intact platelets were incubated at $37{ }^{\circ} \mathrm{C}$ for $5 \mathrm{~min}$ while platelet membranes were incubated at $25{ }^{\circ} \mathrm{C}$ for $60 \mathrm{~min}$. The reaction was stopped by washing the filters with $3 \times 5 \mathrm{ml}$ of ice-cold washing buffer (Tris $\mathrm{HCl} 50 \mathrm{mM}$ pH 7.5, EDTA $1 \mathrm{mM}, \mathrm{MgCl}_{2}$ $5 \mathrm{mM}, \mathrm{NaCl} 100 \mathrm{mM}$ ). Bound and free radioactivity was separated by filtration through Whatman GF/B glass fiber filters for intact platelets or through nitrocellulose filters for platelet membranes using a Brandel cell harvester. Filterbound radioactivity was counted using a liquid scintillation counter. Assays were performed in triplicate in three independent experiments.

Data analysis

Data binding was analyzed with the program EBDALIGAND [25]. The dissociation constant $\left(K_{\mathrm{D}}\right)$ of the radioligand and the inhibition constant for the drug $\left(K_{\mathrm{I}}\right)$ were calculated using the GraphPad software package (GraphPad, San Diego, CA, USA). The results are presented as the mean \pm SEM averaged from three or more independent experiments.

\section{Results}

$\left[{ }^{3} \mathrm{H}\right] \mathrm{PSB}-0413$ is a selective $\mathrm{P} 2 \mathrm{Y}_{12}$ antagonist radioligand

Platelet aggregation induced by $5 \mu \mathrm{M}$ ADP is completely inhibited by $100 \mathrm{nM}$ of the selective antagonist radioligand $\left[{ }^{3} \mathrm{H}\right] \mathrm{PSB}-0413$ (Fig. 1a) while the P2 $\mathrm{Y}_{1}$-dependent shape change, reflected by the initial decrease in light transmission upon addition of ADP, is preserved (Fig. 1b). The selectivity of $\left[{ }^{3} \mathrm{H}\right] \mathrm{PSB}-0413$ was further confirmed using $\mathrm{P}_{2} \mathrm{Y}_{1}$ and $\mathrm{P} 2 \mathrm{Y}_{12}$ transfected $1321 \mathrm{~N} 1$ cell lines. Binding only occurred in $\mathrm{P} 2 \mathrm{Y}_{12}$ transfected cells, while no binding was observed in control or $\mathrm{P}_{2} \mathrm{Y}_{1}$ transfected cells (Fig. 1c). Furthermore, the binding of $\left[{ }^{3} \mathrm{H}\right] \mathrm{PSB}-0413$ was completely abolished in the presence of $10 \mu \mathrm{M}$ of the $\mathrm{P}_{2} \mathrm{Y}_{12}$ selective antagonist ARC69931MX (Fig. 1c).

Binding properties of $\left[{ }^{3} \mathrm{H}\right] \mathrm{PSB}-0413$ to intact human platelets

In a first series of experiments, we wanted to establish the general binding properties of $\left[{ }^{3} \mathrm{H}\right] \mathrm{PSB}-0413$ toward intact platelets. The kinetic of association was very fast $\left(t_{1 / 2}\right.$ of $26.7 \pm 3.9 \mathrm{~s}$ ), and the steady-state was reached within $5 \mathrm{~min}$ (Fig. 2a). After $15 \mathrm{~min}$ incubation, the dissociation was initiated by the addition of $1 \mathrm{mM}$ ADP and the residual binding measured over time during $30 \mathrm{~min}$ (Fig. 2b). The kinetic of dissociation was also fast $\left(t_{1 / 2}=42.9 \pm 10.8 \mathrm{~s}\right)$, and dissociation was completed after $30 \mathrm{~min}$ incubation. 
Fig. 1 Pharmacological characterization. a $\left.{ }^{3} \mathrm{H}\right] \mathrm{PSB}-$ 0413 was obtained by catalytic hydrogenation using tritium gas with a specific radioactivity of 1.85 to $3.7 \mathrm{TBq} / \mathrm{mmol}$ where

${ }^{3} \mathrm{H}$ was fixed on the propyl moieties (black stars). b

Washed platelets were activated with $5 \mu \mathrm{M}$ ADP in the presence of human fibrinogen and in the absence or presence of $100 \mathrm{nM}$ of $\left[{ }^{3} \mathrm{H}\right] \mathrm{PSB}-0413$. c $1321 \mathrm{~N} 1$

cell lines transfected with $\mathrm{P} 2 \mathrm{Y}_{12}, \mathrm{P}_{2} \mathrm{Y}_{1}$ receptors or control (empty vector) were incubated with $1 \mathrm{nM}$ of $\left[{ }^{3} \mathrm{H}\right]$ PSB-0413 at $37^{\circ} \mathrm{C}$ for $5 \mathrm{~min}$. Binding was performed in the presence (closed square) or absence (open square) of $10 \mu \mathrm{M}$ of the $\mathrm{P}_{2} \mathrm{Y}_{12}$ antagonist AR-C69931MX. Assays were performed in triplicate in three independent experiments
A<smiles>CCCSc1nc(N)c2ncn([C@@H]3O[C@H](COP(=O)(O)OP(=O)(O)C(Cl)(Cl)P(=O)(O)O)[C@@H](O)[C@H]3O)c2n1</smiles>

$\left[{ }^{3} \mathrm{H}\right]$ PSB-0413 (1.85-3.7 TBq/mmol)

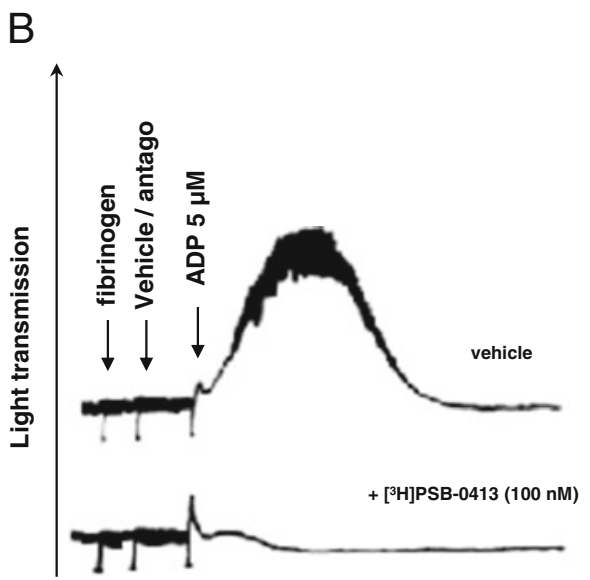

C

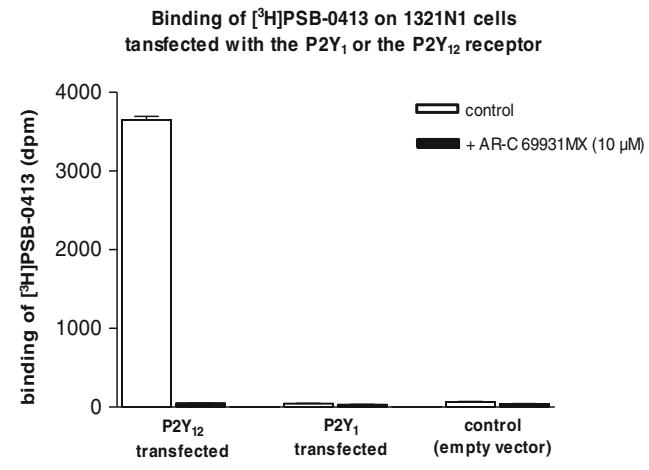

Saturation on intact human platelets is reached with concentration range of $30 \mathrm{nM}\left[{ }^{3} \mathrm{H}\right] \mathrm{PSB}-0413$, and under these conditions, non-specific binding in the presence of $1 \mathrm{mM}$ of ADP was $7.5 \%$ of total binding (Fig. 2c). Saturation curves generated on intact platelets from ten healthy volunteers revealed a single type of binding site with a high affinity $\left(K_{\mathrm{D}}\right)$ of $3.3 \pm 0.6 \mathrm{nM}$ and number of binding sites $\left(B_{\max }\right)$ of $425 \pm 50$ sites per platelet (Fig. 2c). Displacement experiments confirmed the known features of the $\mathrm{P} 2 \mathrm{Y}_{12}$ receptor with the expected rank order of potency of various ligands: $K_{\mathrm{I}}=1.5 \pm 0.26 \mathrm{nM}$ (AR-C69931MX), $32.1 \pm$ $3.03 \mathrm{nM}$ (2MeSADP), $7.3 \pm 1.76 \mu \mathrm{M}$ (ADP $\beta S$ ), and $75 \pm$ $29.3 \mu \mathrm{M}$ (ADP), while the $\mathrm{P}_{2} \mathrm{Y}_{1}$ ligand MRS2179 and the $\mathrm{P}^{2} \mathrm{X}_{1}$ ligand $\alpha, \beta$-Me-ATP at $100 \mu \mathrm{M}$ did not displace the binding of $\left[{ }^{3} \mathrm{H}\right] \mathrm{PSB}-0413$ at concentrations below the millimolar range (Fig. 2d). Saturation experiments on intact platelets from two patients (A and B) with known severe $\mathrm{P}^{2} \mathrm{Y}_{12}$ deficiency $[6,18]$ displayed virtually no binding, while one patient with dysfunctional $\mathrm{P}_{2} \mathrm{Y}_{12}$ (C) [19] displayed normal binding (Table 1).

Effects of thiol reagents on $\left[{ }^{3} \mathrm{H}\right] \mathrm{PSB}-0413$ binding

Clopidogrel, one of the most prescribed $\mathrm{P}_{2} \mathrm{Y}_{12}$ targeting drugs, is a prodrug of which the active liver metabolite is a thiol reagent which covalently binds to cysteine moieties of the $\mathrm{P} 2 \mathrm{Y}_{12}$ receptor. Other thiol reagents were previously reported to target the $\mathrm{P} 2 \mathrm{Y}_{12}$ receptor $[4,9,26-28]$. We thus wanted to check whether these compounds have an effect on the binding of $\left[{ }^{3} \mathrm{H}\right] \mathrm{PSB}-0413$. The reducing agents parachloromercuribenzene sulfonic acid ( $p$ CMBS) or dithiothreitol (DTT) inhibited the binding of $\left[{ }^{3} \mathrm{H}\right] \mathrm{PSB}-0413$ on intact cells in a dose-dependent manner with $K_{\mathrm{I}}$ of $17.3 \pm$ $2.8 \mu \mathrm{M}$ for $p$-CMBS (Fig. 3a) and a $K_{\mathrm{I}}$ of $62.8 \pm 15.2 \mu \mathrm{M}$ for DTT (Fig. 3b). The evaluation of the effect of clopidogrel on $\left[{ }^{3} \mathrm{H}\right] \mathrm{PSB}-0413$ binding to intact platelets was performed in mice treated by clopidogrel $50 \mathrm{mg} / \mathrm{kg}$, a dose that inhibits $100 \%$ platelet aggregation by ADP [29]. Control mouse platelets display $643 \pm 87\left[{ }^{3} \mathrm{H}\right] \mathrm{PSB}-0413$ binding sites/platelet with a $K_{\mathrm{D}}=14 \pm 4.5 \mathrm{nM}$ (Fig. $3 \mathrm{c}$ ). The binding of $\left[{ }^{3} \mathrm{H}\right]$ PSB-0413 to platelets from clopidogrel treated mice was completely abolished.

\section{Binding of $\left[{ }^{3} \mathrm{H}\right] \mathrm{PSB}-0413$ to platelet membranes}

Saturation experiments showed that the radioligand bound to a single class of binding sites with a $K_{\mathrm{D}}=6.5 \pm 3.6 \mathrm{nM}$ and a $B_{\max }=0.5 \pm 0.2 \mathrm{pmol} / \mathrm{mg}$ in human platelet membranes (Fig. 4a) and $K_{\mathrm{D}}=9.1 \pm 5.3 \mathrm{nM}$ and $B_{\max }=0.7 \pm 0.3 \mathrm{pmol} /$ $\mathrm{mg}$ in mouse platelet membranes (Fig. $4 \mathrm{~b}$ ). The binding of $\left[{ }^{3} \mathrm{H}\right] \mathrm{PSB}-0413$ to mouse platelet membrane preparations was completely abolished after clopidogrel treatment. Similarly the direct competitive $\mathrm{P}_{2} \mathrm{Y}_{12}$ antagonist ARC69931MX inhibited the binding, while the $\mathrm{P}_{2} \mathrm{Y}_{1}$ ligand MRS2179 had only minimal effect at concentrations above $100 \mu \mathrm{M}$ (Fig. 4c). 


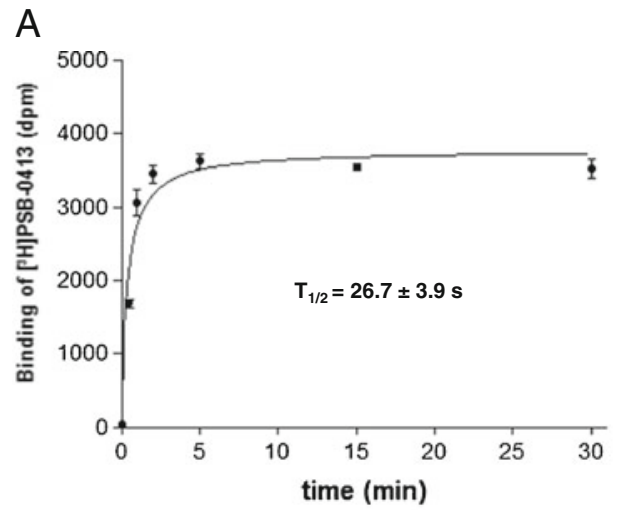

C
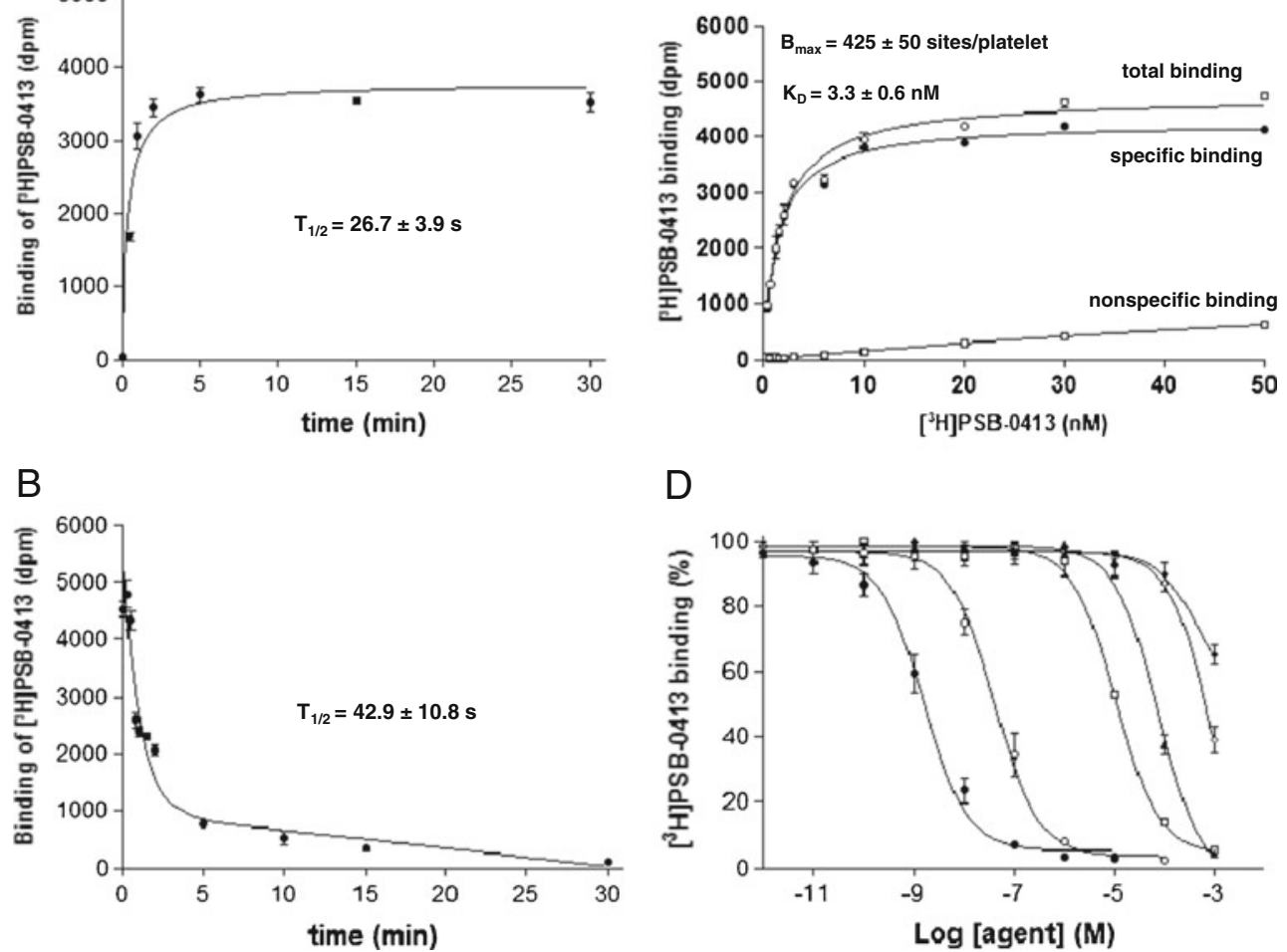

Fig. 2 Binding and pharmacological properties of $\left[{ }^{3} \mathrm{H}\right] \mathrm{PSB}-0413$ on human intact platelets. a Association kinetic of $\left[{ }^{3} \mathrm{H}\right] \mathrm{PSB}-0413$ binding on human intact platelets, measured at $37^{\circ} \mathrm{C}$ over $30 \mathrm{~min}$. b Dissociation kinetic was measured after $\left[{ }^{3} \mathrm{H}\right]$ PSB-0413 binding had reached a steady state $(15 \mathrm{~min})$ and was initiated by addition of $1 \mathrm{mM}$ ADP. Association and dissociation curves are representative from three independent experiments. c Saturation experiment on human intact platelets from ten healthy subjects was achieved using different concentrations of $\left[{ }^{3} \mathrm{H}\right] \mathrm{PSB}-0413$ ranging from 0.05 to $50 \mathrm{nM}$ (closed circle). Non-specific binding assessed in the presence of excess ADP

\section{Discussion}

Reliable methodology for the quantification of $\mathrm{P}_{2} \mathrm{Y}_{12}$ receptor binding sites as well as their characterization is crucial for advancing our understanding of a variety of conditions. For example, there is a debate on whether the platelet $\mathrm{P} 2 \mathrm{Y}_{12}$ receptor rapidly desensitizes and undergoes trafficking upon

Table 1 Binding studies of $\left[{ }^{3} \mathrm{H}\right] \mathrm{PSB}-0413$ on intact platelets from patients with selective inherited $\mathrm{P}_{2} \mathrm{Y}_{12}$ deficiencies

\begin{tabular}{lllll}
\hline & Control & Patient A & Patient B & Patient C \\
\hline$B_{\max }($ sites/platelet $)$ & $425 \pm 50$ & 0 & 0 & 420 \\
$K_{\mathrm{D}}(\mathrm{nM})$ & $3.3 \pm 0.6$ & $\mathrm{nc}$ & $\mathrm{nc}$ & 3.6
\end{tabular}

Saturation experiments were performed on human intact platelets from two patients $(\mathrm{A}, \mathrm{B})$ with severe $\mathrm{P} 2 \mathrm{Y}_{12}$ deficiency $[6,18]$ and one patient with dysfunctional $\mathrm{P}_{2} \mathrm{Y}_{12}$ (C) [19] and on ten healthy donors as control. The number of binding sites $\left(B_{\max }\right)$ and the affinity constant $\left(K_{\mathrm{D}}\right)$ were calculated using EBDA-LIGAND software

$n c$ not calculated

$(1 \mathrm{mM})$ and isotherm binding curves were calculated using the software EBDA-LIGAND in the hot-saturation mode. The saturation curve is representative of ten independent experiments. d Competition experiments were performed at $37{ }^{\circ} \mathrm{C}$ after a 5 -min incubation with $5 \mathrm{nM}$ of $\left[{ }^{3} \mathrm{H}\right] \mathrm{PSB}-0413$ in the presence of increasing concentration of: AR-C69931MX (closed circle), 2MeSADP (open circle), ADP $\beta \mathrm{S}$ (open square), ADP (closed triangle), $\alpha, \beta$-Me-ATP (open diamond), and MRS2179 (closed diamond). Competition curves are the mean of three independent experiments

agonist activation [30-36]. Similarly, polymorphisms of the P2 $\mathrm{Y}_{12}$ receptor have been proposed to be associated with a gain of function in terms of platelet activation and an increased risk of cardiovascular disease [37-41], but the relative densities and binding properties of the platelet $\mathrm{P} 2 \mathrm{Y}_{12}$ receptor associated with these polymorphisms are not known. Finally, patients with inherited $\mathrm{P} 2 \mathrm{Y}_{12}$ defects may present with total absence of receptor expression $[6,18,42]$ while other express abnormal receptors with modified binding properties or normal binding properties and, likely, defective signal transduction [19,42], which require fine characterization $[4,20,42]$. The $\left[{ }^{3} \mathrm{H}\right] \mathrm{PSB}-0413$ selective $\mathrm{P} 2 \mathrm{Y}_{12}$ radioligand was reported recently with only preliminary evaluation as a selective tool using membrane preparations [16] but not intact platelets from healthy control, patients with inherited $\mathrm{P}_{2} \mathrm{Y}_{12}$ defects, $\mathrm{P}_{2} \mathrm{Y}_{12}$ targeting drugs treated patients or animals. The data reported here establish $\left[{ }^{3} \mathrm{H}\right] \mathrm{PSB}-0413$ as a valuable new radioligand to investigate mechanistic aspects of the $\mathrm{P}_{2} \mathrm{Y}_{12}$ receptor in these and other conditions. 
A

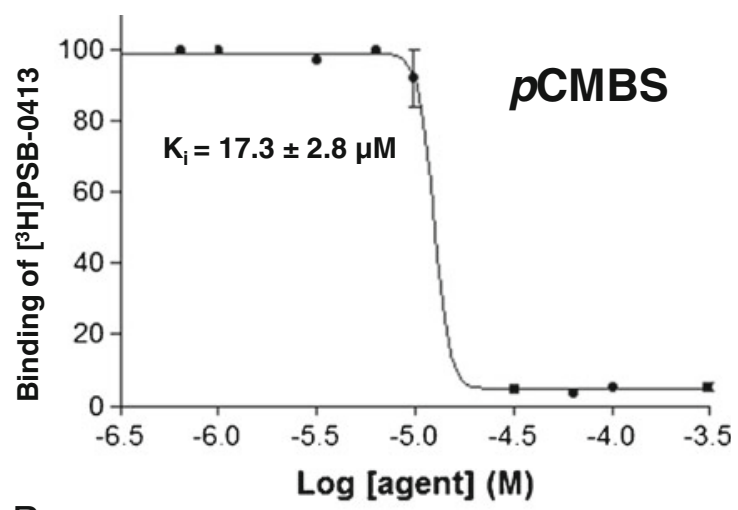

B

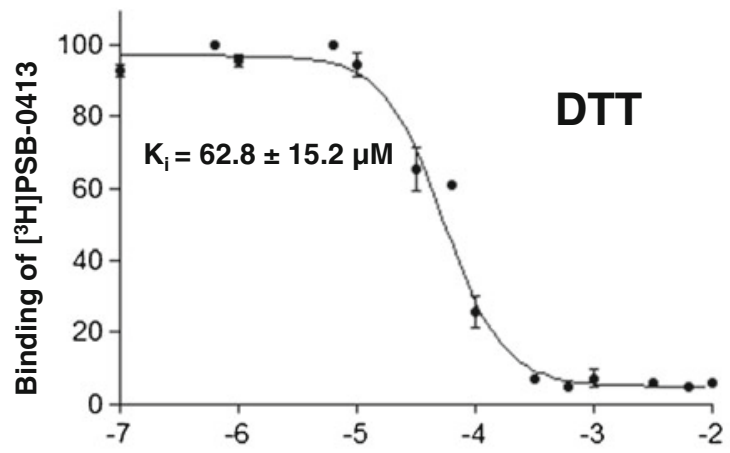

Log [agent] (M)

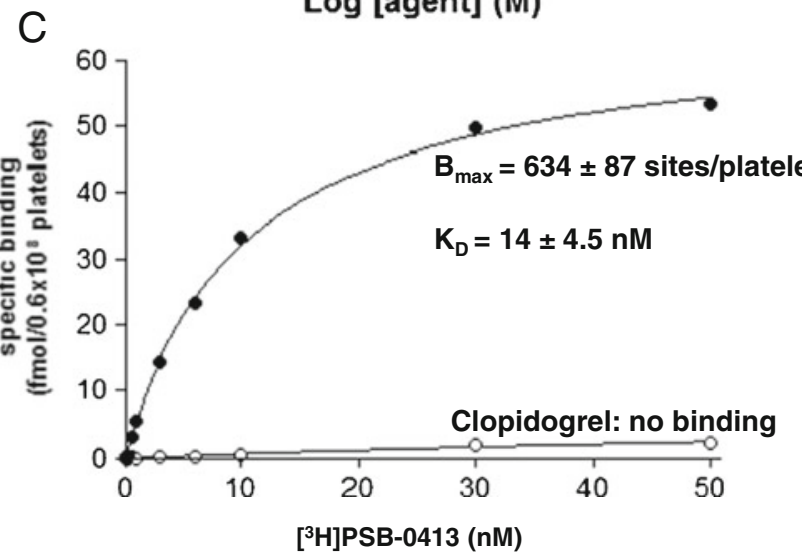

Fig. 3 Effects of thiol reagents on $\left[{ }^{3} \mathrm{H}\right] \mathrm{PSB}-0413$ binding to intact human and mouse platelets. a, $\mathbf{b}$ Inhibition experiments were performed by incubating $5 \mathrm{nM}$ of $\left[{ }^{3} \mathrm{H}\right] \mathrm{PSB}-0413$ with intact platelets pretreated for 10 min with increasing concentrations of thiol reagents: a $p$ CMBS and b DTT; inhibition curves are the mean of three independent experiments. c Saturation experiment was achieved on intact platelets from control mice (closed circle) or from mice that had been treated with $50 \mathrm{mg} / \mathrm{kg}$ clopidogrel (open circle) using concentrations of [ $\left.{ }^{3} \mathrm{H}\right] \mathrm{PSB}-$ 0413 ranging from 0.05 to $50 \mathrm{nM}$. The saturation curve is representative from three independent experiments

Not surprisingly, we found that clopidogrel completely inhibited the binding of $\left[{ }^{3} \mathrm{H}\right] \mathrm{PSB}-0413$ in intact mouse platelets, and it is not hazardous to speculate that it does the same in human platelets. However, we were happy to be able to measure the effect of clopidogrel in membrane preparations (Fig. 4c) as we were not able to do so in a
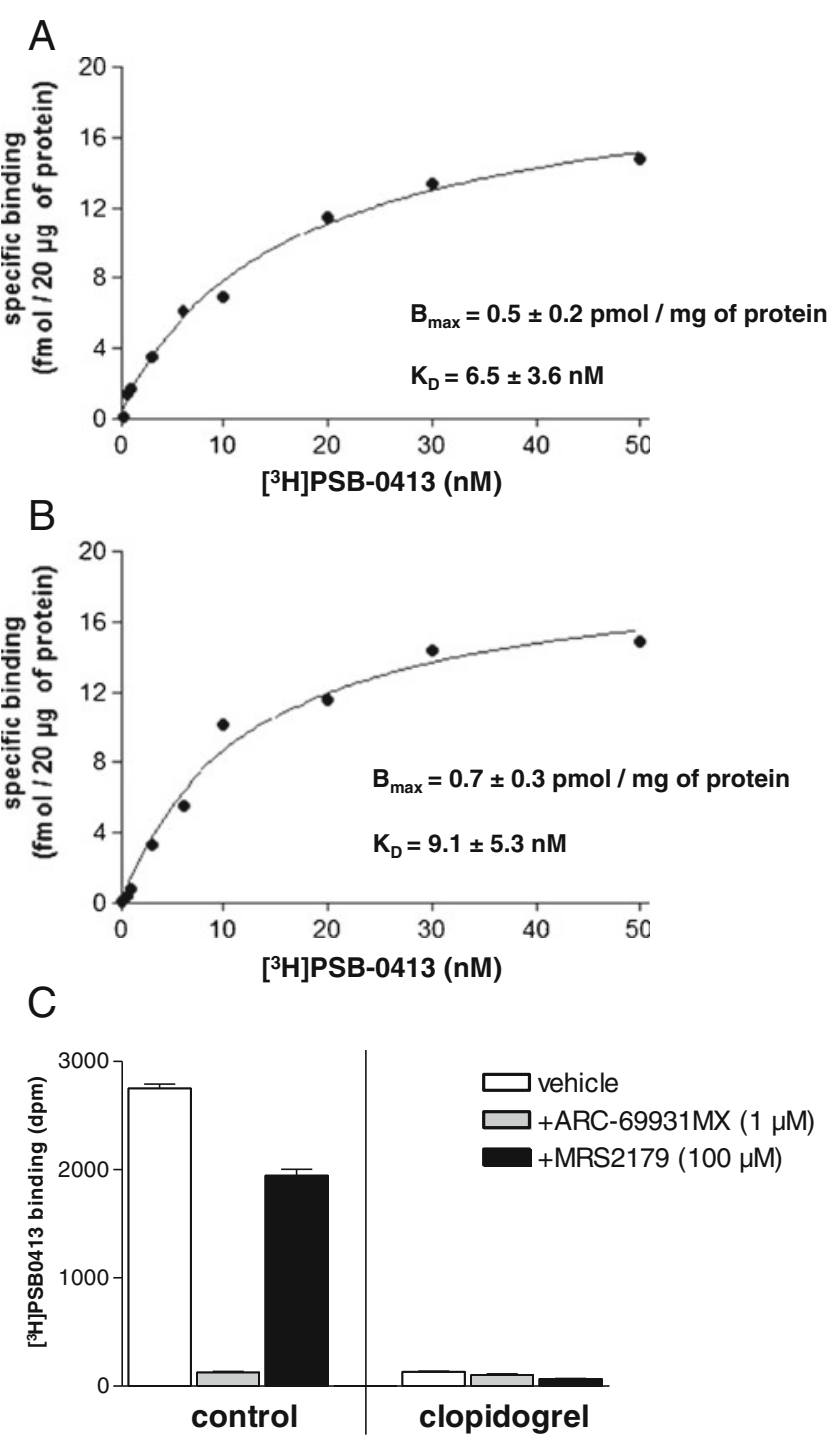

Fig. 4 Binding and pharmacological properties of $\left[{ }^{3} \mathrm{H}\right] \mathrm{PSB}-0413$ on platelet membranes. Saturation experiments on $\mathbf{a}$ human or $\mathbf{b}$ mice platelet membrane preparations were achieved by incubating $20 \mu \mathrm{g}$ of membrane proteins at $25{ }^{\circ} \mathrm{C}$ for $60 \mathrm{~min}$ with different concentrations of $\left[{ }^{3} \mathrm{H}\right] \mathrm{PSB}-0413$ ranging from 0.030 to $50 \mathrm{nM}$. c Binding on platelet membranes from control or clopidogrel $(50 \mathrm{mg} / \mathrm{kg})$ treated mice was achieved using $5 \mathrm{nM}$ of $\left[{ }^{3} \mathrm{H}\right] \mathrm{PSB}-0413$ in the absence (white square) or presence of $1 \mu \mathrm{M}$ AR-C69931MX (gray square) or $100 \mu \mathrm{M}$ MRS2 179 (black square). Assays were performed in triplicate in three independent experiments

previous study using $\left[{ }^{33} \mathrm{P}\right] 2 \mathrm{MeSADP}$ and membrane preparations from clopidogrel treated rats [11]. In fact, reasoning that clopidogrel acts through an active metabolite that covalently binds the cysteine residues of the $\mathrm{P}_{2} \mathrm{Y}_{12}$ receptor, we thought to evaluate the impact of DTT itself on the binding of $\left.{ }^{3} \mathrm{H}\right] \mathrm{PSB}-0413$. As expected, DTT strongly inhibited the binding as did the chemical $p$ CMBS which is a well-known inhibitor of ADP-induced platelet aggregation [9,26-28,43]. Since DTT was present in our previous membrane preparations to preserve them from oxidation, it is not surprising 
that we could not observe any difference between clopidogrel treated and control rats. We now have a clear explanation of the previous failure to measure the effect of clopidogrel on platelet membrane preparations.

Overall, the results presented here do not dramatically differ from previous studies using non-selective radioligands. However, new tools now exist to clearly distinguish and properly quantify the $\mathrm{P}_{2} \mathrm{Y}_{12}$ receptor in the one hand and the $\mathrm{P}_{2} \mathrm{Y}_{1}$ receptor on the other hand using $\left[{ }^{3} \mathrm{H}\right]$ PSB-0413 and the $\left[{ }^{32} \mathrm{P}\right] \mathrm{MRS} 2500[14]$ or $\left[{ }^{125} \mathrm{I}\right] \mathrm{MRS} 2500$ [15] radioligands, respectively. Such studies will be very helpful not only in the platelet field but also in any other cell type and tissues where these receptors display regulated expression [44].

\section{Conclusion}

$\left[{ }^{3} \mathrm{H}\right] \mathrm{PSB}-0413$ is an accurate and selective tool for radioligand binding studies aimed at quantifying $\mathrm{P}_{2} \mathrm{Y}_{12}$ receptors, to identify patients or quantify the effect of $\mathrm{P}_{2} \mathrm{Y}_{12}$ targeting drugs.

\section{References}

1. Gachet C (2006) Regulation of platelet functions by P2 receptors. Annu Rev Pharmacol Toxicol 46:277-300

2. Savi P, Herbert JM (2005) Clopidogrel and ticlopidine: P2Y12 adenosine diphosphate-receptor antagonists for the prevention of atherothrombosis. Semin Thromb Hemost 31(2):174-183

3. Cattaneo M (2010) New P2Y(12) inhibitors. Circulation 121 (1):171-179

4. Cattaneo M (2011) Bleeding manifestations of congenital and drug-induced defects of the platelet $\mathrm{P} 2 \mathrm{Y} 12$ receptor for adenosine diphosphate. Thromb Haemost 105(Suppl 1):S67-74

5. Lips JP, Sixma JJ, Schiphorst ME (1980) Binding of adenosine diphosphate to human blood platelets and to isolated blood platelet membranes. Biochim Biophys Acta 628(4):451-467

6. Cattaneo M, Lecchi A, Randi AM, McGregor JL, Mannucci PM (1992) Identification of a new congenital defect of platelet function characterized by severe impairment of platelet responses to adenosine diphosphate. Blood 80(11):2787-2796

7. Jefferson JR, Harmon JT, Jamieson GA (1988) Identification of high-affinity (Kd $0.35 \mathrm{mumol} / \mathrm{L})$ and low-affinity (Kd 7.9 mumol/ L) platelet binding sites for ADP and competition by ADP analogues. Blood 71(1):110-116

8. Savi P, Laplace MC, Maffrand JP, Herbert JM (1994) Binding of $\left[{ }^{3} \mathrm{H}\right]-2$-methylthio ADP to rat platelets - effect of clopidogrel and ticlopidine. J Pharmacol Exp Ther 269(2):772-777

9. Macfarlane DE, Srivastava PC, Mills DC (1983) 2 Methylthioadenosine[beta-32P]diphosphate. An agonist and radioligand for the receptor that inhibits the accumulation of cyclic AMP in intact blood platelets. J Clin Invest 71(3):420-428

10. Macfarlane DE (1992) 2-Methylthioadenosine [beta-32P]diphosphate: synthesis and use as probe of platelet ADP receptors. Methods Enzymol 215:137-142

11. Gachet C, Cattaneo M, Ohlmann P, Hechler B, Lecchi A, Chevalier J, Cassel D, Mannucci PM, Cazenave JP (1995) Purinoceptors on blood platelets: further pharmacological and clinical evidence to suggest the presence of two ADP receptors. Br J Haematol 91 (2):434-444

12. Baurand A, Raboisson P, Freund M, Leon C, Cazenave JP, Bourguignon JJ, Gachet C (2001) Inhibition of platelet function by administration of MRS2179, a P2Y1 receptor antagonist. Eur J Pharmacol 412(3):213-221

13. Jacobson KA, Boeynaems JM (2010) P2Y nucleotide receptors: promise of therapeutic applications. Drug Discov Today 15(1314):570-578

14. Houston D, Ohno M, Nicholas RA, Jacobson KA, Harden TK (2006) [32P]2-Iodo-N6-methyl-(N)-methanocarba-2'-deoxyadenosine-3',5'-bisphosphat e ([32P]MRS2500), a novel radioligand for quantification of native P2Y1 receptors. Br J Pharmacol 147(5): 459-467

15. Ohlmann P, de Castro S, Brown GG Jr, Gachet C, Jacobson KA, Harden TK (2010) Quantification of recombinant and platelet P2Y (1) receptors utilizing a [(125)I]-labeled high-affinity antagonist 2iodo-N(6)-methyl-(N)-methanocarba-2'-deoxyadenosine-3', 5'bisphosphate ([(125)I]MRS2500). Pharmacol Res 62(4):344-351

16. El-Tayeb A, Griessmeier KJ, Muller CE (2005) Synthesis and preliminary evaluation of $\left[{ }^{3} \mathrm{H}\right] \mathrm{PSB}-0413$, a selective antagonist radioligand for platelet P2Y12 receptors. Bioorg Med Chem Lett 15(24):5450-5452

17. Baqi Y, Atzler K, Kose M, Glanzel M, Muller CE (2009) Highaffinity, non-nucleotide-derived competitive antagonists of platelet P2Y12 receptors. J Med Chem 52(12):3784-3793

18. Cattaneo M, Lecchi A, Lombardi R, Gachet C, Zighetti ML (2000) Platelets from a patient heterozygous for the defect of P2CYC receptors for ADP have a secretion defect despite normal thromboxane $\mathrm{A} 2$ production and normal granule stores: further evidence that some cases of platelet 'primary secretion defect' are heterozygous for a defect of $\mathrm{P} 2 \mathrm{CYC}$ receptors. Arterioscler Thromb Vasc Biol 20(11):E101-106

19. Cattaneo M, Zighetti ML, Lombardi R, Martinez C, Lecchi A, Conley PB, Ware J, Ruggeri ZM (2003) Molecular bases of defective signal transduction in the platelet $\mathrm{P} 2 \mathrm{Y} 12$ receptor of a patient with congenital bleeding. Proc Natl Acad Sci USA 100(4):19781983

20. Cattaneo M (2011) The platelet P2Y receptor for adenosine diphosphate: congenital and drug-induced defects. Blood 117 (7):2102-2112

21. Cazenave JP, Ohlmann P, Cassel D, Eckly A, Hechler B, Gachet C (2004) Preparation of washed platelet suspensions from human and rodent blood. Methods in Mol Biol (Clifton NJ 272:13-28

22. Kauffenstein G, Hechler B, Cazenave JP, Gachet C (2004) Adenine triphosphate nucleotides are antagonists at the $\mathrm{P} 2 \mathrm{Y}$ receptor. $\mathrm{J}$ Thromb Haemost 2(11):1980-1988

23. Barber AJ, Jamieson GA (1970) Isolation and characterization of plasma membranes from human blood platelets. J Biol Chem 245 (23):6357-6365

24. Broekman MJ (1992) Homogenization by nitrogen cavitation technique applied to platelet subcellular fractionation. Methods Enzymol 215:21-32

25. Munson PJ, Rodbard D (1980) Ligand: a versatile computerized approach for characterization of ligand-binding systems. Anal Biochem 107(1):220-239

26. Cristalli G, Mills DC (1993) Identification of a receptor for ADP on blood platelets by photoaffinity labelling. Biochem J 291(Pt 3):875-881

27. Ding Z, Kim S, Dorsam RT, Jin J, Kunapuli SP (2003) Inactivation of the human $\mathrm{P} 2 \mathrm{Y} 12$ receptor by thiol reagents requires interaction with both extracellular cysteine residues, Cys17 and Cys270. Blood 101(10):3908-3914

28. Margaritis A, Priora R, Frosali S, Di Giuseppe D, Summa D, Coppo L, Di Stefano A, Di Simplicio P (2011) The role of protein 
sulfhydryl groups and protein disulfides of the platelet surface in aggregation processes involving thiol exchange reactions. Pharmacol Res 63(1):77-84

29. Gachet C (2008) P2 receptors, platelet function and pharmacological implications. Thromb Haemost 99(3):466-472

30. Baurand A, Eckly A, Bari N, Leon C, Hechler B, Cazenave JP, Gachet C (2000) Desensitization of the platelet aggregation response to ADP: differential down-regulation of the P2Y1 and P2cyc receptors. Thromb Haemost 84(3):484-491

31. Baurand A, Eckly A, Hechler B, Kauffenstein G, Galzi JL, Cazenave JP, Leon C, Gachet C (2005) Differential regulation and relocalization of the platelet $\mathrm{P} 2 \mathrm{Y}$ receptors after activation: a way to avoid loss of hemostatic properties? Mol Pharmacol 67(3):721-733

32. Hardy AR, Conley PB, Luo J, Benovic JL, Poole AW, Mundell SJ (2005) P2Y1 and P2Y12 receptors for ADP desensitize by distinct kinase-dependent mechanisms. Blood 105(9):3552-3560

33. Mundell SJ, Luo J, Benovic JL, Conley PB, Poole AW (2006) Distinct clathrin-coated pits sort different $\mathrm{G}$ protein-coupled receptor cargo. Traffic (Copenhagen, Denmark) 7(10):1420-1431

34. Hoffmann C, Ziegler N, Reiner S, Krasel C, Lohse MJ (2008) Agonist-selective, receptor-specific interaction of human P2Y receptors with beta-arrestin-1 and -2 . J Biol Chem 283(45): 30933-30941

35. Nisar S, Daly ME, Federici AB, Artoni A, Mumford AD, Watson SP, Mundell SJ (2011) An intact PDZ motif is essential for correct P2Y12 purinoceptor traffic in human platelets. Blood 118(20): $5641-5651$

36. Schaff M, Receveur N, Bourdon C, Ohlmann P, Lanza F, Gachet C, Mangin P (2012) beta-Arrestin-1 participates in thrombosis and regulates integrin alphallb-beta3 signalling without affecting P2Y receptors desensitization and function. Thromb Haemost 107:735748

37. Fontana P, Dupont A, Gandrille S, Bachelot-Loza C, Reny JL, Aiach M, Gaussem P (2003) Adenosine diphosphate-induced platelet aggregation is associated with $\mathrm{P} 2 \mathrm{Y} 12$ gene sequence variations in healthy subjects. Circulation 108(8):989-995

38. Fontana P, Gaussem P, Aiach M, Fiessinger JN, Emmerich J, Reny JL (2003) P2Y12 H2 haplotype is associated with peripheral arterial disease: a case-control study. Circulation 108(24):29712973

39. Fontana P, Remones V, Reny JL, Aiach M, Gaussem P (2005) $\mathrm{P} 2 \mathrm{Y} 1$ gene polymorphism and ADP-induced platelet response. J Thromb Haemost 3(10):2349-2350

40. Bierend A, Rau T, Maas R, Schwedhelm E, Boger RH (2008) P2Y12 polymorphisms and antiplatelet effects of aspirin in patients with coronary artery disease. Br J Clin Pharmacol 65 (4):540-547

41. Staritz P, Kurz K, Stoll M, Giannitsis E, Katus HA, Ivandic BT (2009) Platelet reactivity and clopidogrel resistance are associated with the $\mathrm{H} 2$ haplotype of the P2Y12-ADP receptor gene. Int $\mathrm{J}$ Cardiol 133(3):341-345

42. Cattaneo M (2011) Molecular defects of the platelet P2 receptors. Purinergic signal 7(3):333-339

43. Macfarlane DE (1981) The effects of methyl mercury on platelets: induction of aggregation and release via activation of the prostaglandin synthesis pathway. Mol Pharmacol 19(3):470-476

44. Burnstock G (2007) Physiology and pathophysiology of purinergic neurotransmission. Physiol Rev 87(2):659-797 